Res Balticae 6, 2000, pp. 69-75.

\title{
OLD PRUSSIAN PARTICIPLES
}

\section{FREDERIK KORTLANDT \\ Leiden}

Prussian appears to have an active present participle in -nts, $-n t-$, an active past participle in -uns, -us-, and a passive past participle in $-t s,-t-$. The latter two are particularly frequent. The Balto-Slavic passive present participle in - $m$ - is reflected in the isolated form poklausimanas, which requires an emendation. I agree with Benveniste (1933: 6) that the form must be corrected to "poklausiman because the predicative adjective should be neuter singular according to the rules of Prussian syntax: Kai as turri auschaudīwings boüt stawìdas madlas ast steismu Tāwan Endangon enimmewingi bhe poklausimanas "Das ich soll gewisz sein solche Bitte sind dem Vatter im Himel angeneme vnd erhöret", where -as was presumably the result of a "transfert fautif des désinences du sujet" stawidas madlas. The rejection of this view by Endzelin (who admits that "ein neutraler nom.s. zu erwarten wäre", 1935: 141) and Stang (who finds the explanation "psychologisch wenig überzeugend", 1966: 446) is a consequence of their comparative background and insufficient appreciation of the peculiarities of Prussian syntax. The form enimumne "angeneme" is unclear and cannot therefore be used as evidence.

When we look at the undisputed participles, it is instructive first to examine the instances in the First and Second Catechisms in comparison with the Enchiridion (cf. Kortlandt 1998):

$\begin{array}{lll}\text { I } & \text { II } & \text { E } \\ \text { taykowuns } & \text { tykynnons } & \text { teiküuns } \\ \text { patickots } & \text { pagauts } & \text { pogauts } \\ \text { gemmons } & \text { gemmons } & \text { gemmons } \\ \text { stenuns } & \text { styienuns } & \text { stinons } \\ \text { scrisits } & \text { skresitzt } & \text { skrīsits } \\ \text { aulawns } & \text { aulauns } & \text { aulauns } \\ \text { encops } & \text { enquoptzt } & \text { enkopts }\end{array}$




$\begin{array}{lll}\text { lesuns } & \text { lysons } & \text { lisons } \\ \text { att skiwuns } & \text { etskyuns } & \text { etskīuns } \\ \text { gobuns } & \text { gubons } & \text { gübons } \\ \text { sindats } & \text { syndens } & \text { sìdons } \\ \text { pergubuns } & \text { pergubons } & \text { pergübons } \\ \text { aulauwussens } & \text { aulaunsins } & \text { aulausins } \\ \text { swintints } & \text { swyntits } & \text { swintints } \\ \text { crixtits } & \text { crixteits } & \text { crixtits } \\ \text { deiwuts } & \text { deywuts } & \text { deiwuts } \\ \text { proklantitz } & \text { preclantyts } & \text { perklantits } \\ \text { dats } & \text { daeczt } & \text { däts } \\ \text { palletan } & \text { praliten } & \text { pralieiton }\end{array}$

The active present participle I sindats, II syndens, E sidons, sidans "sitzend" suggests a form / sindants/ which was replaced by the active past participle /sidons/ in the Enchiridion. Other instances of the $n t$-participle in the Enchiridion are: dilants "Arbeiter" $(2 x)$, skellänts, skellants, schkellānts "schuldig", nom.pl. skellānts, skellāntei, skellāntai, acc.sg. rīpintin, rīpintin<ton> "folgende", nidruwintin "vngleubige", acc.pl. emprijki waitiaintins "Widersprecher", warguseggientins "Vbeltheter", gen.sg. masc. niaubillintis "vnmündigen", dat.sg. fem. nianbillintai, and emprijkisins "gegenwertig", dat.sg. emprīkisentismu, gerund giwāntei "lebendig", stānintei, stāninti "stehendt". Apart from the gerund, all of these examples appear to be lexicalized forms, so that there is no evidence for an active present participle as a living category in the Enchiridion. This may explain the replacement of / sindants/ by the active past participle /sidons/. The gerund was evidently an uninflected form, as is clear from the syntax of Nostan poquelbton adder stānintei "Darauff kniendt oder stehendt". Note that the ending of nom.pl. skellänts in kai ioūs skellānts astai "was jr schüldig seid" may actually represent the original nom.pl. ending of the consonant stems *-es, while skellāntei and skelläntai show the regular pronominal and nominal endings. The gen.sg. ending of niaubillintis is regularly built on the acc.sg. ending -in (cf. Van Wijk 1918: 73).

Turning to the stem formation of the $n t$-participle, we may note that the forms in -ānt- are thematic $<{ }^{*}$-ont- while the forms in -intcan be thematic, e.g. waitiaintins $<{ }^{*}-\overline{a j}$ jont-, cf. seggientins, or athe- 
matic < $<^{*}$ nt-, e.g. ripintin (cf. Kortlandt 1987). The formation of -sins, -sentismu is of particular interest because it shows an original alternation between zero and full grade (cf. Van Wijk 1929: 162). Since the $e$-grade in the dat.sg. form must have been taken from the casus recti, the zero grade in the nom.sg. form cannot possibly have been taken from the oblique cases and must be original. It follows that we must reconstruct a Balto-Slavic nom.sg. form *esints, which is in accordance with Beekes' theory (1985: 64-77). This reconstruction is supported by the corresponding Old Lithuanian participle in Daukša's Postille, for which Kudzinowski lists the following ablaut grades of the root (1977: 127f.):

$\begin{array}{lll}\text { nom.sg. masc. } & \text { es- } & s- \\ \text { nom.sg. fem. } & 62 & \text { zero } \\ \text { gen.sg. masc. } & 10 & 10 \\ \text { gen.sg. fem. } & 2 & 7 \\ \text { dat.sg. } & 6 & 10 \\ \text { acc.sg. masc. } & \text { zero } & 4 \\ \text { acc.sg. fem. } & 7 & 33 \\ \text { inst.sg. } & 2 & 7 \\ \text { loc.sg. } & 3 & 2 \\ \text { nom.pl. masc. } & 9 & 2 \\ \text { nom.pl. fem. } & 33 & \text { zero } \\ \text { gen./dat./acc. pl. } & 1 & 8 \\ \text { uninflected } & \text { zero } & 11 \\ & \text { zero } & 2\end{array}$

The statistics show that the masc. nom.pl. form represents the original neuter singular *esint which was used predicatively, not the original finite 3rd pl. form *sent(i). For the verb eiti "to go", Kudzinowski lists the following ablaut grades of the root in the ntparticiple (1977: 194):

$\begin{array}{lll} & e i- & e-<{ }^{*} j e- \\ \text { nom.sg./pl. masc. } & 4 & \text { zero } \\ \text { other cases } & \text { zero } & 14\end{array}$

This distribution confirms Beekes' analysis of Latin iens (1985: 70). 
The active past participle ends in -uns or -ons. Elsewhere I have argued that /o/ was a variant of $/ a /$ and $/ u$ / which became phonemicized as a result of the Prussian progressive accent shift (1988: 90). If the accent shifted in gemmons "geborn", as I think it did, the ending -ons is regular under the stress in all three catechisms. In the parallel texts, the unstressed ending is written $I-w u n s(2 x)$, $-w n s$, II -uns (2x), E -uns (3x) after a vowel and I -uns (4x), II -ons $(3 \mathrm{x}),-$ uns, $\mathrm{E}$-ons $(5 \mathrm{x})$ after a consonant. This is evidently the result of an analogical substitution of -ons for -uns after the accent shift. For other instances of the $u s$-participle I refer to Trautmann, who counts for the masc. nom.sg. form $81 x-u n s, 3 x-w u n s, 35 x-o n s, 8 x$ -ans, and once -ins for -uns in the whole corpus (1910: 255). I regard deviations from the expected distribution of -ons and -uns as irregularities and occurrences of -ans or -ins as mistakes. In the Enchiridion I find 9x-uns for -ons after a consonant and no instances of -ons for -uns after a vowel, further $8 \mathrm{x}$-ans, once -as and once -ins for -ons (9x) or -uns (once). An appreciation of these instances requires an examination of the place in the text where they occur because the number of incorrect forms appears to increase toward the end of the text, as I intend to show in more detail on another occasion. For practical purposes I divide the Enchiridion into six parts:

Trautmann Königsberg Dresden Number of

$\begin{array}{lllll}\text { E0 } & 19 & 17 & 1 & \begin{array}{l}\text { pages } \\ \text { half }\end{array} \\ \text { E1 } & 23-51 & 27-77 & 11-61 & 26 \\ \text { E2 } & 51-61 & 79-97 & 63-81 & 10 \\ \text { E3 } & 61-69 & 99-109 & 83-93 & 6 \\ \text { E4a } & 69-77 & 111-123 & 95-107 & 7 \\ \text { E4b } & 77-81 & 125-133 & 109-117 & 5\end{array}$

E3 is the "Trawbüchlein"and E4 is the "Tauffbüchlein". The instances of -uns for -ons are found in E2 (2x), E3 (3x), and E4 (4x). The only instance of -ans for -uns is found in E1, viz. tāns ast etskians "er ist aufferstanden", where -ans was evidently adjusted to tāns. The other instance of -ans in E1 is found in the line after the disputed form poklausimanas, viz. tans sups ast noūmas laipinnans "er 
selbs hat vns geboten", where dat.pl. noūmas is an elliptic variant of regular noummans. The other instances of -ans are found in E4a (once) and $\mathrm{E} 4 \mathrm{~b}(5 \mathrm{x})$, and the only instance of -ins is found on the last page but one of E4b. The producer of the text was evidently in a hurry at this stage. Nothing interesting can be said about the form gubas "gegangen" in E2, which is used imperativally, like enmigguns "geschlaffen" on the following page.

The form in -uns (with variants) is frequently used as a nom.pl. form $(12 x)$, which suggests that the phonetic loss of the original ending *-es of the consonant stems obliterated the distinction between singular and plural here. The alternative nom.pl. ending -usis $(4 \mathrm{x})$ is evidently built on the acc.pl. ending -usins. The alternation of the root vowel between gemmons and acc.sg. ainangimmusin "Eingebornen" suggests the existence of the same original ablaut as in the $n t$-participle. The fem. nom.sg. form aulause "todt" shows that this proterodynamic formation adopted the corresponding hysterodynamic flexion in Prussian (cf. Kortlandt 1997: 162).

I have little to add about the passive past participle in $-t$ Elsewhere I have discussed the accent and vocalism of enkopts "begraben" (1988: 90f.), crixtits "getaufft", skrisits "gecreutziget", pralieiton "vergossen" (1998: 124), and the acc.sg. and neuter forms in -ton (1978: 288-290). The masc. nom.pl. ending is nominal -ai (4x) or pronominal $-e i(2 \mathrm{x})$; the alternative zero ending in the predicative forms isrankit "erlöset", perklantit bhe ismaitint "verdampt vnd verlorn", empijrint "versamlet" is suspect because all four instances are found on two successive pages in E4a, which renders their probative value negligible. 


\section{References}

Beekes, Robert S.P. 1985. The Origins of the Indo-European Nominal Inflection (Innsbruck: Institut für Sprachwissenschaft).

Benveniste, Emile. 1933. Le participe indo-européen en -mno-. Bulletin de la Société de Linguistique de Paris, 34, 5-21.

Endzelin, Jan. 1935. Was ist im Altpreussischen aus ide. ō (und $\bar{a}$ geworden? Studi Baltici, 4, 135-143.

Kortlandt, Frederik. 1978. On the history of the genitive plural in Slavic, Baltic, Germanic, and Indo-European. Lingua, 45, 281-300.

Kortlandt, Frederik. 1987. The formation of the Old Prussian present tense. Baltistica, 23/2, 104-111.

Kortlandt, Frederik. 1988. Van Wijk's Altpreussische Studien revisited. Studies in Slavic and General Linguistics, 12, 89-97.

Kortlandt, Frederik. 1997. Baltic $\overrightarrow{\mathrm{e}}-$ and $\overline{\mathbf{i}} / \mathrm{j} \overline{\mathrm{a}}$-stems. Baltistica, $32 / 2,157-163$.

Kortlandt, Frederik. 1998. The language of the Old Prussian catechisms. Res Balticae, 4, 117-129.

Kudzinowski, Czesław. 1977. Indeks-Stownik do 'Daukšos Postile' I (Poznań: Uniwersytet im. Adama Mickiewicza).

Stang, Christian S. 1966. Vergleichende Grammatik der Baltischen Sprachen (Oslo: Universitetsforlaget).

Trautmann, Reinhold. 1910. Die Altpreußischen Sprachdenkmäler (Göttingen: Vandenhoeck \& Ruprecht).

Van Wijk, Nicolaas. 1918. Altpreussische Studien (Haag: Nijhoff).

Van Wijk, Nicolaas. 1929. Zum altpreußischen Imperativ und zum litauischen Permissiv. Indogermanische Forschungen, 47, 161168. 


\section{Old Prussian participles}

Frederik Kortlandt (Leiden)

The Balto-Slavic passive present participle in - $m$ - is reflected in the isolated form poklausimanas, which requires an emendation. There is no evidence for an active present participle as a living category in the Enchiridion. This may explain the replacement of /sindants/ by the active past participle /sidons/. The formation of -sins, -sentismu is of particular interest because it shows an original alternation between zero and full grade. We must reconstruct a Balto-Slavic nom.sg. form *esints, which is supported by the corresponding Old Lithuanian participle in Daukša's Postille; the masc. nom.pl. form represents the original neuter singular *esint.

The active past participle ends in -uns or -ons. The ending -ons is regular under the stress in all three catechisms. In the Enchiridion I find $9 x-u n s$ for -ons after a consonant and no instances of -ons for - uns after a vowel. I regard deviations from the expected distribution of -ons and -uns as irregularities and occurrences of -ans or -ins as mistakes. The alternation of the root vowel between gemmons and acc.sg. ainangimmusin "Eingebornen" suggests the existence of the same original ablaut as in the $n t$-participle. The fem. nom.sg. form aulause "todt" shows that this proterodynamic formation adopted the corresponding hysterodynamic flexion in Prussian. 